\title{
Messiaanse vredestichters: Intertekstuele relaties tussen Zacharia 9-14 en het Evangelie van Matteüs
}

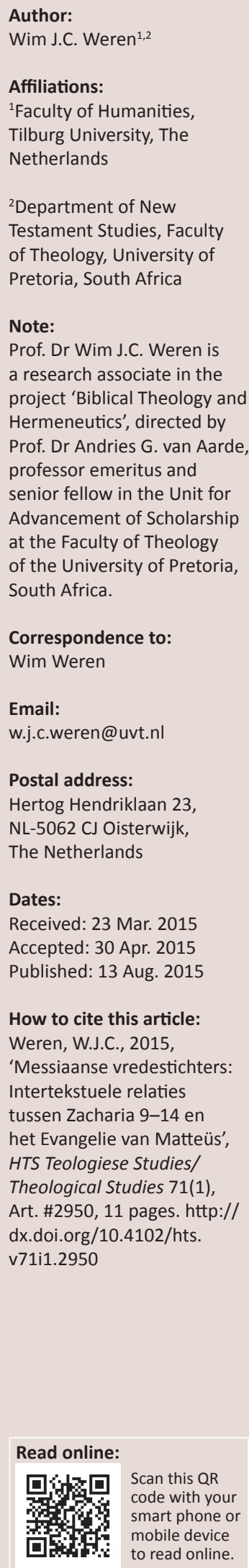

Messianic peacemakers: Intertextual relationships between Zechariah 9-14 and the Gospel of Matthew. This article deals with images of war, violence and peace and with the role of messianic leaders in Deutero-Zechariah and the way in which texts from Zechariah 9-14 have been interpreted in the Gospel of Matthew. The first section describes the lines of meaning in Zechariah 9-14 on the basis of word fields related to violence and universal peace. The second section discusses Deutero-Zechariah's own position in the development of messianic expectations in Old Testament texts. In the third section, the question is asked how the meaning of texts from Zechariah 9-14 about messianic leaders has been influenced by earlier prophetic texts, and how these texts in their turn have been transformed and updated in the Gospel of Matthew, which contains explicit quotations from Deutero-Zechariah in 21:5; 26:15; 26:31 and 27:9-10. The fourth section summarises some interesting semantic shifts appearing in Matthew's gospel compared to Deutero-Zechariah. Moreover, some critical comments are presented against the idea defended in some recent studies that there is a sharp tension between Jesus's role in Matthew as the bringer of a peaceful ethical message, and his violent and vindictive role at the final judgement. At the end of this article, the burning question is raised whether Zechariah's and Matthew's messages, both of which are characterised by a certain degree of exclusivity, can play a constructive role in modern multi-religious discussions about common roads leading to global peace.

\section{Inleiding}

Dit artikel gaat over beelden van oorlog, geweld en vrede in Deutero-Zacharia en over de wijze waarop deze stof geactualiseerd en getransformeerd is in het evangelie van Matteüs. ${ }^{1}$ Daarbij let ik in het bijzonder op de rol van messiaanse figuren. Dat zijn actanten die God terzijde staan in zijn strijd om een heilvolle toekomst te realiseren. De keuze voor Zacharia en Matteüs is allerminst toevallig, want het lijnenspel in Zacharia 9-14 heeft in het evangelie van Matteüs op diverse plaatsen sporen nagelaten. In het geval van expliciete citaten is dat vrij evident; in het geval van allusies is de herkenbaarheid veel geringer.

In deze bijdrage hanteer ik recent ontwikkelde literaire analysemodellen, waarbij ik een uitgesproken voorkeur heb voor tekstsemantiek en intertekstualiteit (Weren 1999:197-215, 2014:91-106). Dit houdt in dat ik tekstuele eenheden uit Zacharia en uit Matteüs opvat als schakels in een lange interpretatiegeschiedenis. In dit artikel beschouw ik teksten uit Matteüs dus als een relecture of réécriture van stof uit Zacharia.

Mijn artikel is als volgt opgebouwd: In de eerste paragraaf probeer ik zicht te krijgen op het lijnenspel in Zacharia 9-14. Dat doe ik aan de hand van woordvelden die verband houden met (oorlogs)geweld en universele vrede. In de tweede paragraaf komt aan de orde welke plaats het boek Zacharia inneemt binnen oudtestamentische profetieën over messiaanse heilsfiguren. In de derde paragraaf onderzoek ik hoe Matteüs in vier expliciete citaten (messiaanse) vormen van leiderschap uit Deutero-Zacharia laat herleven in zijn portretten van Jezus als koning en herder. In de vierde paragraaf ga ik in op de spanningsvolle verhouding in de christologie van Matteüs tussen irenische en gewelddadige aspecten. Ik sluit mijn betoog af met de vraag naar de relevantie van de visie van Matteüs voor hedendaagse pogingen om speren om te smeden tot snoeimessen.

1.Graag draag ik dit artikel op aan mijn collega en vriend professor Pieter de Villiers die aan de wieg heeft gestaan van de NAVNUTconferenties die in 2008 en 2011 in Stellenbosch en in 2015 in Potchefstroom zijn gehouden en die vooral ook door zijn gastvrijheid en inzet een groot succes zijn geworden. 


\section{Geweld en universele vrede in Zacharia 9-14}

Het boek Zacharia bestaat uit twee delen die sterk van elkaar verschillen (Meyers \& Meyers 1992:1061-1065; Petersen 1992:1065-1068). In Zacharia 1-8 luidt het komen van God een periode in van vrede voor de teruggekeerde Joodse ballingen en voor de naburige volkeren. De herbouwde tempel van Jeruzalem gaat weer dienst doen als Gods woonstee; het volk kan zich verheugen in twee ideale leiders, de gouverneur Zerubbabel en de hogepriester Jozua; en de omringende volkeren sluiten zich aan bij Israëls verering van JHwH als de ene en enige God. ${ }^{2}$ Daar staat tegenover dat in het tweede deel, Zacharia 9-14, sprake is van politieke instabiliteit, van bloedige oorlogen tegen de volkeren en van strafexpedities van JHWH tegen zijn eigen volk en hun corrupte leiders.

Op het eerste gezicht lijken de hoofdstukken 9-14 een chaotisch geheel. Toch zijn hier enkele rode lijnen te ontwaren. De tekst bevat over de hele linie woorden die betrekking hebben op wapentuig, op militaire operaties tegen naburige volkeren en op interne conflicten binnen Gods eigen volk, maar ook termen die een vreedzame wijze van samenleven in beeld brengen. Ook spelen messiaanse leidersfiguren een rol, als tegenpool van de corrupte machthebbers, maar dat zijn figuren met heel verschillende gezichten. ${ }^{3}$

In de loop van de zes hoofdstukken die Deutero-Zacharia telt, wordt niet steeds hetzelfde scenario beschreven. Er zijn wel constanten, maar de diversiteit overheerst. Geïnspireerd door Ellul (1981:55-71), Hobbs (1996:103-128), Schellenberg (2001:101-115), Roberts (2004:2-22) en Gonzalez (2013:10), maak ik onderscheid tussen vier scenario's:

1. Het eerste scenario is dominant in 9:1-10:12 en verloopt als volgt: Jнwн treedt op als de nationale God van Israël en verslaat de erfvijanden van zijn volk. Zo schept hij vrede voor Jeruzalem en vanuit Sion wordt de vrede door de messiaanse koning verbreid over de hele wereld.

2. Een tweede scenario is te vinden in 11:1-17. Hier staan interne spanningen en conflicten in de eigen gemeenschap centraal. God trekt nu ten strijde tegen corrupte hoeders van zijn kudde die de sociale en economische orde ontwrichten en religieus syncretisme tolereren. Hij wordt bijgestaan door zijn profeet die hij tot tweemaal toe in een rollenspel laat blootleggen hoe verdorven de situatie is en laat zien dat het verderf zal leiden tot de totale ondergang van Gods kudde.

2.Zie Meyers en Meyers (1992:1063): "Jerusalem at the center is part of Yehud, of the international community of nations, and of the cosmos as ordered by Yahweh.'

3.Tot het semantisch veld /wapentuig/ behoren onder meer de lexemen 'vesting' 'strijdwagens', 'paarden' (strijdrossen), 'pijl', '(strijd)boog' en 'zwaard'. Onder militaire operaties/ ressorteren bij voorbeeld 'belegering', 'strijden', 'wegvagen', en 'door vuur verteren'. Bij deze opsomming is uitgegaan van de woordkeuze in de Herziene Statenvertaling (2010). Het cluster/interne conflicten/ wordt voornamelijk ingekleurd door metaforen die betrekking hebben op herders en hun kudde ingekleurd door metaforen die betrekking hebben op herders en hun kudde. De typische kenmerken van /messiaanse figuren/ komen naar voren in de arme of deemoedige koning van Sion en in de figuur van een herder die verworpen, gewond en gedood wordt. Het semantisch kenmerk /duurzame vrede/ speelt een rol in he wegdoen van wapens, de terugkeer van ballingen naar hun land van herkomst, de hereniging van Juda en Efraim, een veilig bestaan rond JHWH, activiteiten als terugzoeken, genezen en verzorgen, gelouterd worden, verkwikt worden doo stromen van levend water, en groene velden die een overvloedige oogst opleveren.
3. In 12:1-13:7 wordt herhaaldelijk gebruik gemaakt van de vage tijdsaanduiding 'op die dag'. Dit onderdeel begint met een aanval van de volkeren op Jeruzalem die door God en de leiders van Juda wordt afgeslagen (12:1-7). Daarna is er sprake van positieve ontwikkelingen: er wordt een geest van mededogen uitgestort over de inwoners van Jeruzalem; zij zullen rouwen over de moord op een niet nader geïdentificeerde heilsfiguur, en in stad en land worden afgoderij en valse profeten uitgeroeid (12:8-13:6). Dit keerpunt ten goede lijkt weer teniet te worden gedaan door een moordaanslag op de herder, waarna de schapen verstrooid raken. Toch is er geen sprake van een totale vernietiging. Weliswaar wordt de meerderheid van de kudde (twee derde) uitgeroeid, maar de rest (een derde) blijft over en gaat, eenmaal gelouterd, het nieuwe verbondsvolk vormen (13:7-9).

4. De climax wordt bereikt in 14:1-21. Hier is het God zelf die de naties ertoe aanzet om Jeruzalem te gaan belegeren en die de stad ook daadwerkelijk door hen laat innemen, wat gepaard gaat met gruwelijke oorlogsmisdrijven. Dit brute geweld is blijkbaar nodig om Jeruzalem te zuiveren van het kwaad. Daarna keert God terug op zijn schreden: hij ontzet de stad, moordt vele veroveraars uit en berooft hen van hun buit. ${ }^{4}$ Het resultaat is dat God nu vanuit Sion kan gaan heersen over een imperium dat zich uitstrekt over heel de aarde. De overgebleven Joden zullen samen met niet-Joden die het door God aangerichte bloedbad overleefd hebben een nieuwe cultusgemeenschap vormen rond JHwH. Daarmee is het beoogde doel bereikt, al was er wel veel grof geweld voor nodig.

\section{Messiaanse vredestichters in Zacharia 9-14}

Met de term 'messiaanse vredestichter' doel ik op een persoon of een groep die onder Gods hoede en namens hem een beslissend keerpunt tot stand brengt in de geschiedenis en zo een periode inluidt waarin mensen in vrijheid en vrede kunnen samenleven. ${ }^{5}$ Binnen mijn definitie is het niet zo dat de bedoelde bevrijder ook expliciet als 'gezalfde' of 'Messias' moet worden aangeduid (contra M. de Jonge 1992:778).

In deze paragraaf schets ik in grote lijnen welke plaats het boek Zacharia inneemt binnen oudtestamentische profetieën over messiaanse heilsfiguren. Deze profetieën borduren voort op Gods belofte dat het koningschap na David blijvend zal worden bekleed door een van zijn nakomelingen (2 Sam 7:12-16). Zijn dynastie is inderdaad eeuwenlang aan de macht gebleven, maar dat betekent niet dat alle vorsten ook ideale heersers waren. Bittere teleurstellingen hebben voedsel gegeven aan de hoop op de komst van een sterk geïdealiseerde heilsfiguur in de lijn van David in de nabije of verre toekomst. In Jesaja 9:5 is sprake van een kind dat 'Vredevorst' (שָׁר־שָׁלום)

4.Parallellen van deze voorstelling zijn te vinden in Joël 4:1-21 en Micha 4:11-13 Zie Roberts (2004:14): 'God first besieges Jerusalem to purge it of evil, and then, when God's purging judgment has accomplished its purpose, God suddenly steps in when God's purging judgment has accomplished its purpose, God
to rescue Jerusalem from the foreign nations gathered against it.'

5. Rose (2000:23) spreekt over 'messiaanse verwachtingen' en betrekt deze term op: 'expectations focusing on a future royal figure sent by God who will bring salvation to God's people and the world.' 
zal worden genoemd. In Jesaja 11:1 wordt de toekomstige koning voorgesteld als een twijgje (נָּטָר), dat ontspruit aan de afgehouwen stronk van Isaï, een loot (נيֶֶ) uit zijn wortels. De messiaanse droom wordt ook vertolkt in Micha 5:1-5. Toen de davidische erfopvolging in 586 strandde, ontstonden tijdens het verblijf van Judese ballingen aan Babels stromen visioenen over het herstel en de vernieuwing van het koningschap. In teksten uit Jeremia (bijv. 23:1-6; 33:14-18) en Ezechiël (17:22-24; 34:22-27; 37:24-28) - evenals in tal van psalmen - wordt de toekomstige vorst ingekleurd als iemand die zich laat leiden door recht en gerechtigheid, en als een ware herder. De bekende teksten uit Deutero-Jesaja over de knecht van JHWH - een fi guur die in Trit o-Jesaja al s een coll ect ief wordt opgevat - getuigen van het nieuwe inzicht dat lijden en vernedering dankzij God kunnen leiden tot verhoging. Door de open houding van de knecht voor de wereld van de volken komt het rijk van universele vrede dichterbij.

Na het in 539 uitgevaardigde decreet van koning Cyrus (Ezra $6: 3-5)$ keert een groep Judese ballingen terug naar hun land van herkomst en krijgt de messiaanse droom nieuwe impulsen door het optreden van de post-exilische profeten Haggaï en Zacharia. ${ }^{6}$ De wederopbouw van de tempel in de jaren 520-516 vormt het centrum van de activiteiten die gericht zijn op het herstel van de Joodse gemeenschap. In dat proces spelen twee figuren een hoofdrol: de locale politieke leider Zerubbabel en de hogepriester Jozua. ${ }^{7}$ In het boek Haggaï worden ze vaak als een duo gepresenteerd $(1: 1,12 ; 2: 2,4)$. Dit geschrift wordt afgesloten met een positief beeld van Zerubbabel: in een passage over wat er in de eindtijd zal geschieden (2:20-23), noemt JHwH hem 'mijn dienaar' en zegt hij: 'Ik zal jou dragen als mijn zegelring, want jou heb ik uitverkozen' (NBV). Als gouverneur van Juda is hij er een teken van dat God vanuit de tempel in Jeruzalem over de hele wereld zal gaan heersen. In Zacharia 3 wordt aan de hogepriester Jozua een taak toebedeeld die in het verleden door de koning werd vervuld: hij moet de tempel besturen en de voorhoven bewaken. In Zacharia 4 wordt de rol van Zerubbabel bij de voltooiing van de wederopbouw van de tempel breed uitgemeten. Zijn naam valt daar herhaaldelijk $(4: 6,7,9,10)$. Hij zal zijn opdracht niet door eigen kracht of macht tot een goed einde weten te brengen maar door de hulp van Gods geest (4:6). De herbouw van de tempel komt opnieuw ter sprake in Zacharia 6, maar in dat verband wordt Zerubbabel niet met name genoemd; wel is daar een bijzondere rol weggelegd voor Jozua, op wiens hoofd een kroon van goud en zilver wordt geplaatst. Naast hem is er sprake van een tweede figuur die 'Spruit' heet en die met majesteit wordt bekleed en zal heersen vanaf zijn troon. Van deze figuur wordt tevens gezegd dat hij de tempel zal herbouwen. Dat hier een tweede figuur in het spel is, wordt bevestigd door het slot van 6:13 waar gezegd wordt

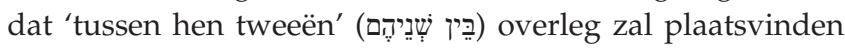
over een vreedzaam bestuur.

6.Met 'Zacharia' is hier de profeet bedoeld aan wie de hoofdstukken 1-8 van het gelijknamige Bijbelboek worden toegeschreven.

7.Volgens Matteüs is Zerubbabel de kleinzoon van koning Jechonja en een van de voorouders van Jezus (Matt 1:12-13).
Dit roept de vraag op wie er in Zacharia 3:8 en 6:12 bedoeld kan

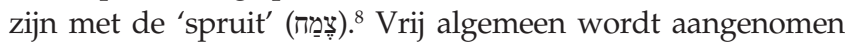
dat deze term in het boek Zacharia slaat op de gouverneur Zerubbabel door wiens optreden de messiaanse droom na de ballingschap weer oplaaide. Argumenten ten faveure van deze interpretatie zijn dat de 'spruit' degene is die de tempel zal herbouwen (Zach 6:12-13). Dat is precies de taak die aan Zerubbabel wordt opgedragen. Daar komt nog bij dat Zerubbabel in Haggaï 2:23 als de dienaar of de knecht van JHWH wordt aangeduid en dat diezelfde titel in Zacharia 3:8 ook op de 'spruit' wordt toegepast. De implicatie van deze zienswijze is dat de lang gekoesterde messiaanse verwachting volgens Zacharia 3 en 6 in het optreden van Zerubbabel, die zelf een nazaat is van koning David, vlees en bloed begint te worden. De politieke leider Zerubbabel werkt nauw samen met de spirituele leider Jozua, die in het boek Zacharia eveneens messiaanse trekken krijgt. Dit wijst op een vorm van een tweehoofdig messiaans bestuur. Dit idee wordt bevestigd door het gegeven dat in Zacharia 6:13 sprake is van twee figuren en zou nog versterkt worden wanneer de twee 'zonen van de olie' in Zacharia 4:14 begrepen mogen worden als twee gezalfden. ${ }^{9}$

Terwijl Zacharia 1-8 overwegend gekenmerkt wordt door hooggestemde verwachtingen, zijn de hoofdstukken 9-14 heel anders van toon. Jozua en Zerubbabel worden daar niet meer genoemd. Het enthousiasme maakt plaats voor teleurstelling en pessimisme. Het idee dat de messiaanse verwachting in de gouverneur en de hogepriester in vervulling begon te gaan, wordt losgelaten en vervangen door uitspraken over figuren die op uiteenlopende manieren worden beschreven. Aan de orde komen een vredevorst (9:9$10)$, een herder die verworpen wordt (11:1-17) en vermoord (13:7-9), en een figuur die doorboord wordt (12:10-11). In zijn strijd wordt God soms bijgestaan door 'het huis van Juda' (9:13; 10:6; 12:4-7; 14:14). De rol van het huis van David is ambivalent (12:7-12; 13:1): soms speelt dit huis een negatieve rol maar soms is het nog altijd de drager van een nieuwe toekomst. We zien hier dus dat messianisme in DeuteroZacharia vele gezichten kan krijgen. $\mathrm{Nu}$ eens lijkt de hoop gevestigd te zijn op een individu, dan weer op een collectief die een kleine minderheid vertegenwoordigt. Alle genoemde figuren worden in zo vage termen beschreven dat ze niet direct gekoppeld kunnen worden aan concrete historische personen of gebeurtenissen. Dit proces gaat gepaard met een steeds verder gaande eschatologisering. ${ }^{10}$

\footnotetext{
8.Deze aanduiding komt buiten het boek Zacharia ook voor in Jesaja 4:2; Jeremia 23:5; 33:15. Volgens Koehler en Baumgartner (1958:807) heft betrekking op het gehele groeiproces ('das Sprossen, Wachstum, Gewächs') als op een individuele scheut (' $d$. einzelne Spross').

9.Diametraal hiertegenover staat de interpretatie van Rose (1998:373-376 en 2000; zie ook Petterson 2009:246-252) dat '[de] Spruit' in Zacharia 3:8 en 6:12 evenals in Jeremia 23:5 en 33:15 - geïdentificeerd moet worden met de nog in de toekomst te verwachten messiaanse koning. Rose's filologisch onderzoek laat zien dat de gangbare opvatting dat צִ geïdentificeerd kan worden met Zerubbabel, op enkele punten discutabel is, maar daar staat tegenover dat zijn eigen visie (צִממח de eigennaam van een nu nog niet te identificeren toekomstige heilsfiguur) soms gepaard gaat met gekunstelde interpretaties. Een voorbeeld daarvan is dat hij de kroon op het hoofd van Jozua ziet als een teken dat moet garanderen dat er in de kroon op het hofor zal redden (Rose 2000:59)

10.Volgens McAfee Moss (2008:17) is deze 'progressive dehistorization of the māšîah. notion' al begonnen in Jesaja 9:6-7 en 11:1. Voor een overzicht van de ontwikkeling notion' al begonnen in Jesaja 9:6-7 en 11:1. Voor een overzicht van de ontwikkeling
van messiaanse verwachtingen in het vroege jodendom zij verwezen naar M. de van messiaanse verwachti
Jonge (1992:781-786).
} 
Literair-historisch gezien is het boek Zacharia dus geen tekstuele eenheid. Volgens de communis opinio in de hedendaagse Bijbelwetenschappen zijn de hoofdstukken $1-8$, die spreken over de wederopbouw van de tempel na de ballingschap in de jaren 520-516 BCE (vgl. Zach 1:1 en 7:1), door een andere auteur op schrift gesteld dan de hoofdstukken 9-14. Het tweede deel zou in de latere Perzische tijd (ca. 450-332 BCE), of misschien zelfs pas tijdens het bewind van Alexander de Grote (332-323 BCE) of tijdens de overheersing van Juda en Jeruzalem door de Ptolemaeën (ca. 320-198 BCE) zijn huidige vorm hebben gekregen. ${ }^{11}$

Doordat het tweede deel slechts spaarzame en onduidelijke verwijzingen bevat naar de sociaal-historische setting, blijft de datering van Deutero-Zacharia onzeker. ${ }^{12}$ Inmiddels is op basis van de sterke verschillen tussen Proto- en Deutero-Zacharia de vruchtbare hypothese ontwikkeld dat Deutero-Zacharia een herinterpretatie is van uitspraken uit Proto-Zacharia en van nog oudere profetische teksten. Toen de positieve beelden uit Proto-Zacharia in de loop van de vijfde eeuw door veranderingen in de sociaal-politieke context hun glans verloren, ontstond er in bepaalde Joodse minderheidsgroepen behoefte aan een update om de stof uit het eerste deel van Zacharia relevant te maken voor hun leven in een door hen als vijandig ervaren omgeving (vgl. Mason 2003b).

Dat Deutero-Zacharia een relecture of Fortschreibung is van oudere profetische teksten leidt Floyd (2003) af uit het

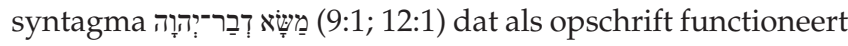
van de twee onderdelen van Deutero-Zacharia (9:1-11:17 en 12:1-14:21) en aangeeft tot welk literair genre deze passages behoren:
... the maśśā' is a prophetic genre defined in terms of its reinterpretive function, and ... Zech. 9-11 and Zech. 12-14 have the term maśśáa as their superscription because they are texts belonging to this specific category .... Defined in rhetorical terms, maśśá' means something like 'prophetic interpretation of a previous revelation'. (pp. 239-240; zie ook Floyd 2002; Weis 1992)

De vroegere openbaring is in dit geval onder meer te vinden in de acht visioenen uit Zacharia 1-8. Wat deze visioenen te betekenen hebben voor latere generaties wordt in de orakels van Deutero-Zacharia ontvouwd. In dat proces worden beweringen uit vroegere teksten herhaald, aangevuld, gecorrigeerd, ontkend of zelfs volkomen omgekeerd.

\section{Lijnen van Deutero-Zacharia naar Matteüs}

In deze paragraaf ga ik na wat teksten uit Deutero-Zacharia over messiaanse vormen van leiderschap te betekenen

\footnotetext{
11.De meeste auteurs pleiten voor een datering in de eerste helft van de vijfde eeuw (bijv. Redditt 1994:664-678), maar er gaan ook stemmen op voor een latere datering, tussen 400 en 350, of onder het bewind van de Ptolemaeën (ca. 300200); zie Gonzalez (2013).

12.Voor de geschiedenis van het jodendom tussen 500 en 200 BCE zie Flavius Josephus, Antiquitates Judaicae, XI, 1-303; Schama (2013:54-86).
}

TABEL 1: Expliciete citaten in Matteüs uit Deutero-Zacharia.

\begin{tabular}{ll}
\hline Passage uit Deutero-Zacharia & Expliciet citaat in Matteüs \\
\hline 9:1-10 & Zacharia 9:9 in Matteüs 21:5 \\
11:1-17 & Zacharia 11:12 in Matteüs 26:15 \\
& Zacharia 11:13 in Matteüs 27:9-10 \\
13:7-9 & Zacharia 13:7 in Matteüs 26:31 \\
\hline
\end{tabular}

hebben in hun eigen literaire setting en hoe daarin stof is verwerkt uit oudere profetische teksten. Tevens ga ik na hoe deze teksten op hun beurt zijn omgewerkt en geactualiseerd in het evangelie van Matteüs. Ik beperk me tot passages uit Deutero-Zacharia die volgens de strenge criteria van Foster (2003:65-84) in het evangelie van Matteüs expliciet worden geciteerd (zie Tabel 1).

\section{Een zachtmoedige koning: het citaat uit Zacharia 9:9 in Matteüs 21:5}

In de Hebreeuwse tekst (Tabel 2) van Zacharia 9:1-10 treedt God op als krijger (Weren 2014:167-177). Hij zal de militaire bolwerken slechten die Efraïm en Juda omringen en op zijn triomftocht zal hij ten slotte in Jeruzalem belanden, waar hij de wacht zal betrekken rond zijn huis. Ook zal hij Efraïm en Juda zuiveren van het daar aanwezige wapentuig. Binnen dit geheel lijkt de aankondiging aan Sion van de intocht in Jeruzalem van 'uw koning' te slaan op de troonsbestijging van JHWH, maar toch is dat niet waarschijnlijk. Dat de koning rechtvaardig is, zou nog op God kunnen slaan, die immers in Zacharia 14:9, 16, 17 als koning te boek staat en als hersteller van recht en gerechtigheid, maar עושי passen niet goed bij God en wijzen eerder in de richting van een menselijke heilsfiguur. ${ }^{13}$ De niphal נושע heeft immers een passieve betekenis ('hij is bevrijd ${ }^{\prime 14}$ ) en duidt erop dat de binnenrijdende koning ook zelf deelheeft aan de door God gebrachte bevrijding. ${ }^{15}$ De term עני heeft een dubbele betekenis (arm, nederig) en plaatst de koning in de lijn van de lijdende dienaar van JHWH die ootmoedig is en vernederd (Jes 53:4, 7). Het rijdier van de koning, een ezel, contrasteert met de strijdrossen in 9:10 die in tijden van oorlog worden ingezet. De koning wordt niet expliciet getypeerd als een nazaat van David. ${ }^{16}$

De messiaanse koning verschijnt pas op het toneel als de strijd gestreden is. Hij zal de door God bereikte vrede

13.De door Köhler (1971:370) voorgestelde vertaling van deze twee termen ('gerecht und siegreich ist er, triumphierend und reitend auf einem Esel') is niet overtuigend.

14. Het participium niphal van dit werkwoord heeft ook elders in het Oude Testament (Deut 33:29; Ps 33:16) een passieve betekenis. De betekenis van Zacharia 9:9 is vooral verwant met de inhoud van Psalm 33:16-17: 'Een koning wordt niet gered door een groot leger, een held wordt niet gered door zijn grote kracht. Het paard geeft valse hoop op de overwinning en kan geen redding brengen in zijn grote kracht'. Ook Psalm 72:7-8 keert zich tegen militarisme en nationalisme; zie ook Larkin (1994:75).

15.In het geval van de actieve vormen van ישע in Zacharia 8:7, 13; 9:16; 10:6; $12: 7$ is God het handelend subject. In de Septuagint is de messiaanse koning zelf een bevrijder: de niphal נושע is hier weergegeven met het actieve participium $\sigma \omega \zeta \omega v$. In 9:10 kiest de Septuagint niet voor de eerste persoon ('ik') maar voor de derde persoon ('hij': $\left.\dot{\varepsilon} \xi_{0} \lambda \varepsilon \theta \rho \varepsilon v ́ \sigma \varepsilon 1\right)$. Het effect van deze wijziging is dat 9:10a in de Griekse tekst direct aansluit bij 9:9 en dat het wegdoen van het wapentuig hier niet door God wordt uitgevoerd maar door de messiaanse koning.

16.Volgens Leske (2000:665-667, 671-672) zijn met de 'koning' Gods getrouwen bedoeld; het woord slaat zijns inziens niet op een individu maar op een groep. Hij verwijst hiervoor naar het collectieve messianisme in Deutero- en Trito-Jesaja. Ook met 'degene die doorboord is' (12:10), is volgens hem een groep bedoeld, namelijk met 'degene die doorboord is' (12:10), is volgens hem een groep b
het huis van Juda. Hetzelfde zou gelden voor 'de heiligen' in 14:5. 
TABEL 2: Zacharia 9:9 in de Hebreeuwse Bijbel en in de Septuagint.

\section{Zacharia 9:9 in de Hebreeuwse Bijbel $\dagger$}

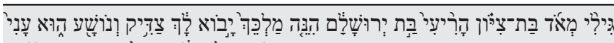

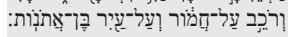

Verheug u zeer, dochter van Sion, juich luid, dochter van Jeruzalem. Zie, uw koning zal tot u komen, rechtvaardig is hij en bevrijd, arm en rijdend op een ezel, op een ezelsveulen, het jong van een ezelin.‡
Zacharia 9:9 in de Septuagint

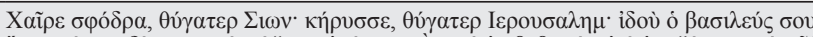

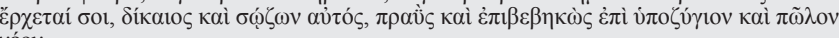
véov.

Verheug u zeer, dochter van Sion, roep het uit, dochter van Jeruzalem. Zie, uw koning komt naar u toe, rechtvaardig is hij en een bevrijder, zachtmoedig en gezeten op een lastdier, een ezelsveulen.

$\dagger$, In deze paragraaf ga ik uit van de reconstructie van de tekst van de Hebreeuwse Bijbel en de Septuagint in hedendaagse kritische edities (Biblia Hebraica Stuttgartensia en de Göttinger editie van de Septuagint). Voor gedegen onderzoek naar de tekstvorm van citaten in Matteüs zij onder meer verwezen naar Steyn (2012:427-446).

$\ddagger$, Eigen vertaling. Ook andere aanhalingen uit de Hebreeuwse Bijbel en de Septuagint zijn in deze bijdrage door mij zo letterlijk mogelijk vertaald.

verbreiden onder alle volkeren en zijn heerschappij zal zich uitstrekken tot de uiteinden van de aarde. ${ }^{17}$ In 9:11-17 nemen Juda, Efraïm en Sion deel aan de strijd. Hun rol wordt in militaire termen beschreven: ze worden vergeleken met een boog, een pijl en een zwaard. Toch is de komst van de nieuwe koning verbonden met positieve ontwikkelingen, zoals de terugkeer van de ballingen en de hereniging van Juda en Efraïm. Gods volk kan nu in veiligheid leven en de aarde brengt overvloedig vruchten voort. Dat zijn manifestaties van de bereikte vrede.

Het citaat in Matteüs 21:5 begint met een oproep die ontleend

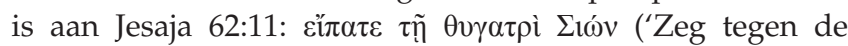
dochter van Sion'). Daarna volgen woorden uit Zacharia 9:9:

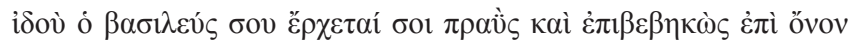

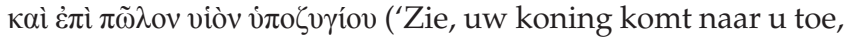
zachtmoedig en gezeten op een ezel en op een veulen, het jong van een lastdier.'). We hebben hier dus te maken met een mengcitaat.

Jesaja 62:11 behoort tot een bepaald genre, dat door Collins (2003:34-37) wordt aangeduid als 'proclamaties van het komen van God'. Dit genre is verwant met het genre 'theofanie'. Proclamaties van het komen van God hebben een min of meer vast patroon: ze beginnen met een oproep in de imperatief aan een bepaalde geadresseerde, en geven daarna de inhoud weer van de boodschap: (1) 'zie'; (2) er komt iemand naar u toe; (3) wie dat is; (4) hoe hij komt; (5) wat het effect zal zijn van zijn komst. Dit patroon is te vinden in Jesaja 30:27; 35:4; 40:9-11; Zacharia 2:10 (14); Sefanja 3:14-15, 16-17. Daaraan kunnen nog andere teksten worden toegevoegd: Jesaja 12:6; $41: 27 ; 52: 1-2,6-8$. In al deze proclamaties is sprake van het komen van God. Juist dat element, dat ook in Proto-Zacharia voorkomt, wordt in Zacharia 9:9 omgebogen: hier is het niet God maar de messiaanse koning die de stad binnenrijdt.

Deze mutatie van het oude schema schept een speelruimte die door Matteüs wordt benut als hij dit schema op Jezus toepast. Hij wijzigt ook de formulering van de eigenschappen van de koning. Dat hij rechtvaardig is wordt weggelaten, hoewel dat uitstekend zou passen in Matteüs' beeld van Jezus. Even opmerkelijk is dat de term $\sigma \omega \dot{\zeta} \zeta \omega v$ niet wordt overgenomen uit de versie van de Septuagint; deze term zou naadloos passen bij de verklaring van de naam Jezus in Matteüs 1:21. Door deze weglatingen valt de klemtoon ten volle op het gegeven dat Jezus, de koning van Sion, zachtmoedig is (zie ook 11:29) en partij kiest voor wie klein en kwetsbaar is. Hij is niet vijandig of

17.Zie Mason (2003a:36): '[T] he king who comes brings victory and deliverance with him for the people. But it is God's victory which he has experienced, and which he mediates to the community by virtue of his right relationship to God.' oorlogszuchtig. Niet de inwoners van Jeruzalem verwelkomen Jezus maar de menigte die met hem is meegereisd vanuit Galilea. Ze noemen hem 'de profeet uit Nazaret' en begroeten hem als 'de zoon van David'. Na zijn aankomst in de stad zuivert hij het tempelplein van commerciële activiteiten die daar verricht worden om de voortgang van de cultus mogelijk te maken. ${ }^{18}$ Jezus typeert de kopers en verkopers als 'rovers'. Dit woord heeft als connotatie dat zij gewapend geweld niet uit de weg gaan. We zien hier dat ook de vredevorst harde acties niet schuwt. Door vervolgens op het tempelplein blinden en lammen te genezen laat Jezus zien in welke richting het alternatief moet worden gezocht voor de praktijken die hij veroordeelt. Zijn daad vormt een fraaie illustratie van het motto uit Hosea 6:6: 'Barmhartigheid wil ik en geen offer' (vgl. 9:13; 12:7). Terwijl Deutero-Zacharia uitloopt op een nieuwe cultusgemeenschap zonder etnische grenzen legt de matteaanse Jezus het primaat bij ethische activiteiten waardoor mensen in nood een humane toekomst krijgen.

\section{Een verworpen herder: Zacharia 11:1-17}

Het beeld van de herder en zijn kudde is al aangestipt in 9:16 waar JHwн zichzelf als de herder presenteert van zijn volk dat zijn kudde is. In 10:2-3 keert dit beeld terug. Nu zegt God dat zijn volk door afgoderij en het optreden van valse profeten ronddoolt als schapen die geen herder hebben ${ }^{19}$ en dat hij zich tegen de herders zal keren en zelf zal omzien naar zijn kudde. Verder komt het beeld van de herder en zijn kudde voor in Zacharia 13:7-9 waar de schapen na de moord op de herder verstrooid raken en slechts een klein deel gered wordt.

De meest uitvoerige uitwerking van het beeld van de herder en zijn kudde is te vinden in Zacharia 11 (zie Brouwer 1949). De inleidende verzen (11:1-3) zijn een omkering van wat er beweerd is in 9:9-10. Was daar sprake van een koning met positieve eigenschappen, nu gaat het over verdorven herders; stond daar de toekomstige redding centraal, nu is er sprake van verwoesting en ondergang; het gejuich van Sion heeft nu plaats gemaakt voor geweeklaag en gejammer. Op de achtergrond klinkt Jeremia 25:34-38 door waar de herders door God worden afgestraft en de kudde wordt uitgemoord zonder dat er sprake is van een sprankje hoop. JHwH verschijnt hier weer in de rol van een geweldenaar die zich ook keert tegen mistoestanden in de kring van zijn eigen volk.

18.Omstreden is of de beschrijving in Matteüs $21: 12$ - 13 alludeert op Zacharia 14:21; zie H.J. de Jonge (2003:87-100).

19. Deze uitdrukking komt ook voor in Numeri 27:17; 1 Koningen 22:17 // 2 Kronieken 18:16; Ezechiël 34:8. Boda and Porter (2005:226) wijzen op intertekstuele relaties tussen Zacharia 10:1-3 en de volgende pre-teksten: Deuteronomium 11:10-17; tussen Zacharia 10:1-3 en de volgende
Jeremia 14:1-15:4; 23:1-3; Ezechiël 34. 
TABEL 3: De interpretatie van Zacharia 11:12b in Matteüs 26:15.

\begin{tabular}{|c|c|c|}
\hline Hebreeuwse tekst Zach 11:12b & Zacharia $11: 12 b$ in de Septuagint & Matteüs 26:15† \\
\hline 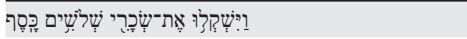 & 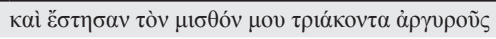 & 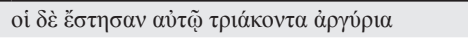 \\
\hline en zij wogen mijn loon af: dertig zilverstukken & en zij stelden mijn loon op dertig zilverstukken. & en zij telden dertig zilverstukken voor hem uit. \\
\hline
\end{tabular}

$\dagger$, De dertig zilverstukken worden ook genoemd in 27:3, 5, 6, 9 .

In 11:4-17 schakelt God een niet met name genoemde figuur in om de vinger op de zere plek te leggen. Waarschijnlijk gaat het hier over de profeet die ook in Proto-Zacharia een rol speelt en daar Zacharia heet. De passage heeft de vorm van een aanstellings- of roepingsverhaal. De door God aangesproken figuur moet de rol van herder gaan spelen en profetische tekenhandelingen verrichten. Misschien is het zelfs zo dat de profeet in zijn rol van herder God zelf moet uitbeelden die de eigenlijke herder is van de kudde. Vandaar ook dat niet altijd duidelijk is of met de ik-figuur de profeet of God zelf is bedoeld. Het optreden van de profeet verloopt in twee fasen. Gewoonlijk wordt aangenomen dat hij eerst de rol krijgt van een goede herder en daarna die van een slechte herder. ${ }^{20}$ Maar evenals Redditt (1993:676-677, 679) ben ik van oordeel dat dit onderscheid niet strookt met de tekst en dat het rollenspel van de profeet in beide fasen een zekere dubbelheid of ambiguiteit vertoont: het is de profeet die van God zijn opdrachten krijgt en die ook uitvoert (en dat is positief) maar hij moet doorlopend uitbeelden dat hijzelf (of God?) in zijn rol van herder wel moet falen, niet alleen vanwege de verdorvenheid van de leiders, maar ook omdat de schapen een afkeer van hem hebben.

Het is moeilijk om de talrijke beelden te relateren aan concrete historische figuren of omstandigheden. $\mathrm{Zo}_{\mathrm{o}}$ is het onduidelijk wie er bedoeld zijn met de drie herders die binnen één maand zijn uitgeroeid (11:8). Opvallend is wel dat financieel-economische termen een grote rol spelen: de herders werken nauw samen met kopers en verkopers die zichzelf verrijken en samen worden aangeduid als veehandelaars $(11: 7,11) .{ }^{21}$ Ook is er sprake van het uitbetalen van een passend loon aan de profeet voor zijn diensten. Hij ontvangt dertig zilverstukken en draagt die af aan de smelter in de tempel. Dit jargon brengt Gonzalez (2013:31) tot het vermoeden dat de herders en handelaars slaan op een elite in de post-exilische Joodse gemeenschap in Jeruzalem die zich onder de Ptolemaeën verrijkte ten koste van lagere klassen en ten koste van de tempel.

Meer zekerheid biedt een intertekstuele aanpak die Zacharia 11:1-17 opvat als een relecture van oudere profetische teksten die de ballingschap interpreteren als een straf voor het falen van de leiders van het volk en waarin God zelf het herderschap van hen overneemt (Ezech 34:11-22, 31). Bij alle kritiek is er in oude profetische teksten echter ook sprake van hoop voor de toekomst. God zal zijn dienaar David aanstellen

20.Volgens Redditt (1993:676) is het beeld nog veel negatiever en speelt de ik-figuur doorlopend de rol van een slechte herder: '[T]he prophet is understood both times to play the role of an evil and foolish shepherd.'

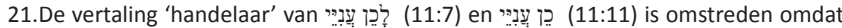
zij berust op de conjectuur dat deze twee woorden samengetrokken moeten zij berust op de conjectuur dat deze twee woorden samengetrokken moeten (Koehler \& Baumgartner 1958:444-445). Deze gissing berust op de Septuagint, die

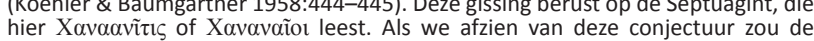

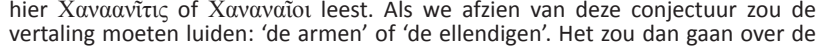
meest kwetsbare dieren van de kudde. als de ene herder van zijn kudde en een vredesverbond ${ }^{22}$ sluiten met het uitgezuiverde volk, zodat het veilig kan wonen, vrij van plunderaars en van verscheurende wilde dieren, en kan genieten van een rijke oogst (Jer 23:1-8; Ezech 34:23-30). Tot het hoopvolle toekomstperspectief behoort ook dat de profeet in Ezechiël 37:15-28 (evenals in Zach 11: 4-16) een symbolische handeling verricht, die hierin bestaat hij twee stukken hout samenvoegt tot één geheel om daarmee duidelijk te maken dat Juda (het vroegere Zuidrijk) en Jozef (het voormalige Noordrijk) herenigd zullen worden.

Juistdituitzichtopeen positieve toekomstontbreektinZacharia $11: 4-17$. Hier is geen sprake van een hereniging maar van een afbraak van de twee koninkrijken, niet van een vernieuwing van het verbond maar van een verbondsbreuk, niet van een toekomstige goede herder maar van het uitschakelen van slechte herders en de teloorgang van hun kudde. DeuteroZacharia is veel somberder gestemd dan Jeremia of Ezechiël. Hij gelooft niet langer in het restauratieprogramma van de vroegere profeten. Zijn tekst eindigt in 11:17 in mineur met een wee-spreuk over 'de nietsnut van een herder die de kudde in de steek laat'. ${ }^{23}$ Met het oog hierop spreekt Redditt (1994:674) van 'a reversal of expectations'. Volgens hem is het huis van David er mede schuldig aan dat vroegere voorspellingen van nationaal herstel onder leiding van de davidische monarchie niet zijn uitgekomen en dat er nu behoefte is aan 'a revised eschatology in which the old prophecies could still come true' (Redditt 1989:640-641).

\section{De interpretatie van Zacharia 11:4-17 in Matteüs 26:15 en 27:3-10}

Volgens Foster (2003:76-79) bevat Matteüs twee citaten uit Zacharia 11. Het eerste citaat is te vinden in Matteüs 26:15 en stamt uit Zacharia 11:12b (Tabel 3).

In Matteüs 26:15 stellen de hogepriesters en oudsten de prijs of waarde van Jezus vast op dertig zilverstukken en geven dat bedrag aan Judas als vergoeding voor zijn diensten. De (dertig) zilverstukken spelen een grote rol in Matteüs' verhaal over het einde van Judas: 27:3, 5-6, 9. In dat verhaal staat nog een tweede citaat uit Zacharia (11:13), en wel in Matteüs 27:9-10 (Tabel 4).

Een vergelijking tussen deze drie versies wijst het volgende uit:

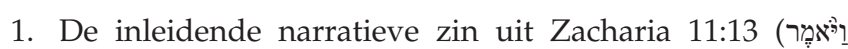

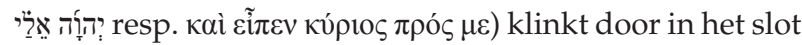

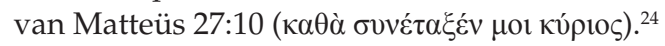

\footnotetext{
22. Het syntagma berith sjalom komt voor in Ezechiël $34: 25 ; 37: 26$.

23.Een wee-spreuk over de herder(s) komt behalve in Zacharia 11:17 ook voor in Jeremia 23:1 en Ezechiël 34:2.

24.Vooral het $\mu$ o in 27:10, dat in Matteüs' verhaal volkomen in de lucht hangt, duidt op een relatie met Zacharia 11:4-16 waar een ik-figuur een grote rol speelt.
} 
TABEL 4: De interpretatie van Zacharia 11:13 in Matteüs 27:9-10.

\begin{tabular}{|c|c|c|}
\hline Hebreeuwse tekst Zacharia 11:13 & Zacharia 11:13 in de Septuagint & Matteüs 27:9-10 \\
\hline 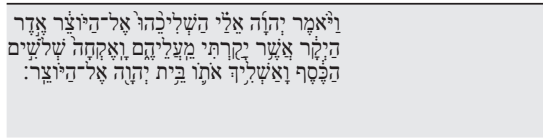 & 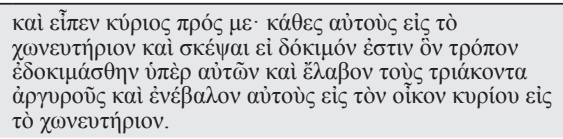 & 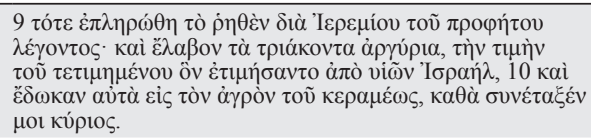 \\
\hline $\begin{array}{l}\text { En JHWH zei tegen mij: 'Smijt dat bij de smelter, die } \\
\text { fraaie prijs waarop ik geschat ben door hen.' Daarop } \\
\text { nam ik de dertig zilverstukken en smeet ze in het huis } \\
\text { van JHWH, bij de smelter. }\end{array}$ & $\begin{array}{l}\text { En de Heer zei tegen mij: 'Plaats ze in de smeltoven en } \\
\text { kijk of de waarde billijk is waarop ik voor hen geschat } \\
\text { ben', en ik nam de dertig zilverstukken en smeet ze in } \\
\text { het huis van de Heer, bij de smeltoven. }\end{array}$ & $\begin{array}{l}\text { Toen is vervuld wat gesproken is door de profeet } \\
\text { Jeremia: en zij namen de dertig zilverstukken, de prijs } \\
\text { waarop sommige zonen van Israël hem die geschat is, } \\
\text { geschat hebben, en zij gaven ze uit voor de akker van de } \\
\text { pottenbakker, zoals de Heer mij had opgedragen. }\end{array}$ \\
\hline
\end{tabular}

2. Het eerste bevel uit Zacharia 11:13 ('smijt ze bij de smelter') is in Matteüs niet opgenomen in het citaat maar is daar al verwerkt in 27:5, waar Judas de zilverstukken de tempel in smijt.

3. De daarop volgende formule uit de Hebreeuwse tekst ('de fraaie prijs waarop ik geschat ben door hen') krijgt een lichtelijk gewijzigde pendant aan het slot van Matteüs 27:9 ('de prijs waarop sommige zonen van Israël hem geschat hadden'). ${ }^{25}$

4. De zinsnede 'ik nam de dertig zilverstukken' keert nagenoeg letterlijk terug in Matteüs, maar dan zo dat ह̌ $\lambda \alpha \beta o v$ niet langer op de ik-figuur betrekking heeft ('ik nam') maar op de hogepriesters en oudsten ('zij namen $\left.^{26}\right)$.

We zien dus dat het citaat op een vrije en creatieve wijze wordt weergegeven, zodat het past in de nieuwe literaire context waarin het door Matteüs is ingevlochten. Ook buiten dit citaat bevat Matteüs 27:3-10 sporen van elementen uit Zacharia 11, vaak in getransformeerde vorm: in 27:3 brengt Judas vol berouw over zijn misstap de dertig zilverstukken terug naar de hogepriesters en oudsten; als blijkt dat zij het geld niet in ontvangst willen nemen, gooit Judas de zilverstukken de tempel in (27:5); de hogepriesters rapen de zilverstukken op maar bergen ze niet op in de schatkist van de tempel omdat het bloedgeld is; daarom zoeken ze er een andere bestemming voor. Deze op elkaar volgende handelingen lopen gedeeltelijk parallel met het handelingsverloop in Zacharia 11, waar de herder de dertig zilverstukken in opdracht van God afdraagt aan de smelter in de tempel met de klaarblijkelijke bedoeling om de edele bestanddelen na het smeltproces toe te voegen aan de tempelschat.

Uit het bovenstaande blijkt hoezeer het verhaal over Judas' einde beïnvloed is door Zacharia 11. Het expliciete citaat in Matteüs 27:9 is dus maar het topje van een ijsberg. De tekst bevat diverse andere - meer impliciete en verholen verwijzingen naar de tekstuele eenheid waaruit het citaat afkomstig is. Matteüs heeft zijn verhaal aangepast aan het citaat, maar ook heeft hij het citaat aangepast aan zijn verhaal.

Vreemd is dat het vervullingscitaat in Matteüs 27:9-10 wordt toegeschreven aan de profeet Jeremia, terwijl toch duidelijk is

\footnotetext{
25.In Matteüs ontbreekt het ironisch bedoelde אָ [de fraaie prijs]. De rol van de slechte herders ('door hen') is in Matteüs overgenomen door de hogepriesters en vertegenwoordigen (van Tilborg 1989:166). Volgens Haubeck en Von Siebenthal (1997:I.191) wordt árò hier gevolgd door een genitivus partitivus.
}

26.Zie ook de pluralis $\check{\delta} \delta \omega \kappa \alpha v$ in 27:12. dat de aanhaling in 27:9 uit Zacharia afkomstig is. De verwijzing naar Jeremia is waarschijnlijk mede ingegeven door de Hebreeuwse term יוֹצֵ die twee keer voorkomt in Zacharia 11:13 en in Matteüs 27:7.10 is weergegeven met de Griekse term $\kappa \varepsilon \rho \alpha \mu \varepsilon u ́ s$, in combinatie met de term 'akker'. Het

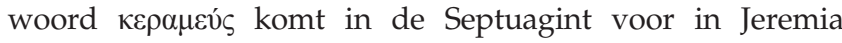
$18: 2,3,6$, maar het probleem is dat daar geen sprake is van een akker van de pottenbakker, terwijl het in Jeremia 32:6-9 wel gaat over de aankoop van een akker maar niet over een akker van een pottenbakker. Er is dan ook weinig reden voor om de woordcombinatie 'de akker van een pottenbakker' uit Matteüs 27:7, 10 op te vatten als een allusie op Jeremia 18 of 32.

Maar waar ligt dan de connectie met het boek Jeremia? Bij de beantwoording van deze vraag kies ik mijn vertrekpunt bij het gegeven dat Matteüs in het vervullingscitaat een handeling opneemt ('en zij gaven die voor het land van de pottenbakker') die niet in Zacharia 11:13 wordt genoemd maar een actie beschrijft die narratief gezien pas plaatsvindt na afloop van de in Zacharia 11:13 genoemde gang van zaken: met het (bloed)geld wordt een akker aangekocht. Volgens 27:7-8 gaat het om de akker van de pottenbakker die de Joodse leiders met het door Judas geretourneerde bloedgeld aankopen om er vreemdelingen te begraven en die tot op de dag van vandaag 'Bloedakker' heet. Aan deze handeling geeft Matteüs een Bijbels fundament doordat hij haar in 27:10 opneemt in het vervullingscitaat, dat hij toeschrijft aan Jeremia, hoewel er van letterlijke overeenkomsten met een tekst uit Jeremia geen sprake is. Wel zijn er volgens verschillende auteurs in Jeremia 19:1-15 diverse elementen te vinden die doen denken aan details in Matteüs' verhaal over het einde van Judas:: ${ }^{27}$ in de Hebreeuwse tekst van Jeremia 19:1, 6 komt een pottenbakker voor (יוצר, vergelijk Matteüs 27:7,10); een echo van 'het bloed van onschuldigen' uit Jeremia 19:4 is te vinden in Matteüs 27:4 ('onschuldig bloed'); in Jeremia 19:2, 6 is sprake van een

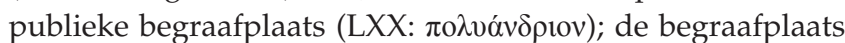
wordt in Jeremia 19:6 'Dal van de Slachting' of 'Moorddal' genoemd, een naam die even onheilspellend klinkt als de 'Bloedakker' in Matteüs 27:8.

Na dit alles stel ik de belangrijkste vraag aan de orde: welke (nieuwe) betekenis krijgen de aan Zacharia 11 ontleende elementen in hun nieuwe literaire setting? Het meest opvallend is dat de rol van de ik-figuur, die in Zacharia 11 al een zekere dubbelheid vertoont, in Matteüs wordt

27.Gundry (1982:557-558); van Tilborg (1989:168-171); Brown (1994:1.651); Davies en Allison (1997:568-569); Foster (2003:77); $\operatorname{Ham}$ (2005:120, 123). 
TABEL 5: De interpretatie van Zacharia 13:7 in Matteüs 26:31

\begin{tabular}{|c|c|c|}
\hline Hebreeuwse tekst Zacharia 13:7 & Zacharia 13:7 in de Septuagint & Matteüs 26:31b \\
\hline 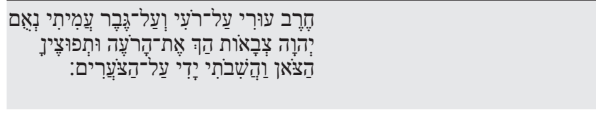 & 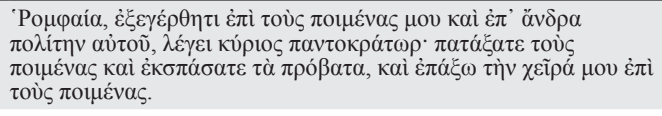 & 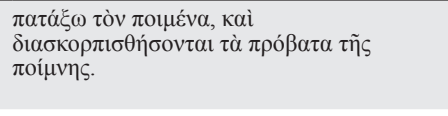 \\
\hline $\begin{array}{l}\text { Zwaard, ontwaak tegen mijn herder, tegen de man die mijn } \\
\text { metgezel is - godspraak van JHWH van de heerscharen. Sla } \\
\text { de herder en de schapen zullen verstrooid worden en ik zal } \\
\text { mijn hand tot de kleinen wenden. }\end{array}$ & $\begin{array}{l}\text { Zwaard, ontwaak tegen mijn herders en tegen zijn medeburger, } \\
\text { zegt de Heer de Albeheerser. Sla de herders en drijf de schapen } \\
\text { uiteen, en ik zal mijn hand richten tegen de herders. }\end{array}$ & $\begin{array}{l}\text { Ik zal de herder slaan, en de schapen van de } \\
\text { kudde zullen verstrooid worden. }\end{array}$ \\
\hline
\end{tabular}

opgesplitst en verdeeld wordt over twee verschillende personages: Judas en Jezus (Noland 2008:144). In Zacharia is degene wiens werk een bepaalde prijs waard is dezelfde figuur als degene die het geld afdraagt aan de tempel; in Matteüs is het Jezus van wie de waarde gesteld wordt op dertig zilverlingen, terwijl het Judas is die het geld incasseert en het even later in de tempel smijt. De ik-figuur in Zacharia laat door symbolische handelingen zien dat een slechte herder zal worden uitgeschakeld, terwijl Judas door de Joodse leiders juist wordt ingehuurd om eraan mee te werken dat er een einde komt aan Jezus' optreden als goede herder (zie 9:36; 15:31). Dit wekt de indruk dat Judas in zijn eentje de rol van de slechte herder krijgt toebedeeld. Toch is dat niet het geval. Hij is slechts een instrument in handen van de Joodse leiders die als de eigenlijke bad guys worden aangemerkt. ${ }^{28}$ Na zijn daad krijgt Judas spijt en zegt hij dat hij 'onschuldig bloed' heeft overgeleverd. Hij is de eerste die de onschuld van Jezus uitspreekt en hij doet dat vlak voor de aanvang van het verhaal over het proces voor Pilatus waarin ook de vrouw van Pilatus en de gouverneur zelf Jezus onschuldig noemen $(27: 19,24)$. Noland (2008) komt op grond van deze tekstuele gegevens tot verhelderende conclusies:

\begin{abstract}
... all the shepherd references in Zechariah are negative; they are all about shepherding that has failed in one way or another. But they implicitly set up a positive image of shepherding, i.e. of the leadership that the people need ... Matthew feels justified in reading into the subsequent shepherd texts a positive counterpart to the failures that are written about. (p. 144)
\end{abstract}

\section{Een vermoorde herder: de interpretatie van Zacharia 13:7 in Matteüs 26:31}

In Matteüs 26:31b staat een partieel citaat uit Zacharia 13:7. Wie of wat is hier bedoeld met 'de herder', en hoe worden de aangehaalde woorden geïnterpreteerd in Matteüs? Zetten we eerst de verschillende versies naast elkaar (Tabel 5).

De drie versies vertonen zowel overeenkomsten als verschillen (Menken 2011:40-44, 48-49). In de Hebreeuwse tekst spreekt God over 'mijn herder', een leidende figuur, die getroffen wordt door een zwaard met als gevolg dat de schapen (de mensen in Juda) overal verspreid worden. De herder wordt ook 'de man die mijn metgezel is' genoemd. ${ }^{29}$ Onduidelijk is of de kleinen aan het slot van 13:7 door Gods hand beschermd of bestraft worden.

28.van Tilborg (1989:166, 168): "The real bad shepherds are the chief priests and the elders.' Hij ziet Jezus als hun antitype.

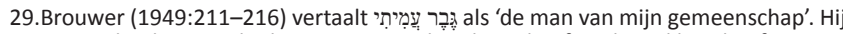
meent dat deze aanduiding een actieve betekenis heeft en betrekking heeft op een messiaanse figuur die het contact van het volk met God herstelt.
De versie van de Septuagint schept een tweedeling tussen de herders (in het meervoud; bedoeld is waarschijnlijk de heersende klasse; zie ook de pluralis in 11:3, 5), die door het zwaard getroffen worden, en de schapen (het gewone volk), die gespaard blijven. ${ }^{30}$

In Matteüs kondigt Jezus aan dat zijn leerlingen vanwege hem nog diezelfde nacht ten val zullen komen en dat dit strookt met de in 26:31 aangehaalde woorden uit Zacharia. Hijzelf is de herder die door God zal worden geslagen. Dat God degene is die de herder zal treffen, blijkt uit de indicativus $\pi \alpha \tau \alpha \dot{\xi} \xi \omega$, die de plaats heeft ingenomen van de imperativi in de Hebreeuwse tekst en de Septuagint. Bij Jezus' arrestatie valt de kudde uiteen en vluchten de leerlingen weg (26:56), maar hun ontrouw zal niet blijvend zijn, want na zijn opwekking zullen zijn leerlingen in Galilea elkaar en hun herder hervinden (28:10, 16-20). Qua formulering vertoont het citaat in Matteüs zowel contactpunten met de Hebreeuwse tekst als met de versie van de Septuagint.

Het lijdt geen twijfel dat 'de herder' in Matteüs 26:31 slaat op Jezus en dat hij een positief te waarderen figuur is die Gods gunst geniet. Maar hoe verhoudt deze interpretatie zich tot de oorspronkelijke betekenis van Zacharia 13:7? Is de herder daar een negatieve of een positieve figuur?

Op zichzelf beschouwd kan de aanslag op de herder begrepen worden als een door God zelf ondernomen afrekening met een leider die vroeger zijn vertrouweling was maar dat nu niet meer is. Zacharia 13:7 vormt dan het dramatisch hoogtepunt in een ontwikkeling die in 11:17 is ingezet: werd de herder daar verminkt, nu wordt hij gedood. Inhoudelijk hangt de moord op de herder ook samen met 12:10 waar sprake is van een figuur 'die zij doorstoken hebben'31, en met 13:3 waar een valse profeet door zijn eigen ouders doorstoken wordt. De dood van de herder heeft desastreuze gevolgen voor de kudde.

Maar hier staan meer positieve gegevens tegenover. In 13:8-9 komt naar voren dat na de dood van de herder weliswaar ook het overgrote deel van de kudde wordt uitgeroeid maar

30. In de Göttinger editie van de Septuagint is gekozen voor de lectio difficilior $\dot{\varepsilon} \pi$

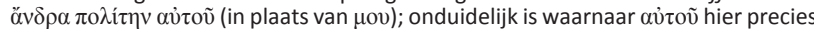
verwijst.

31.De vertaling en interpretatie van de Hebreeuwse tekst van Zacharia 12:10

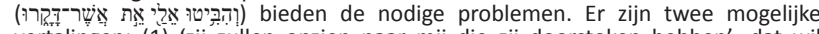
vertalingen: (1) 'zij zullen opzien naar mij die zij doorstoken hebben'; dat wil zeggen dat het volk de spreker, namelijk God, heeft doorstoken; (2) 'zij zullen opzien naar mij vanwege hem die zij doorstoken hebben'; in dit geval is er een onderscheid tussen God en degene die doorstoken is. Niet verkieslijk is de visie dat de mensen van Juda zullen opzien naar God vanwege die Joden die gedood zijn in de vrijheidsstrijd tegen vreemde overheersers. Deze interpretatie valt niet te verzoenen met de formulering van de Hebreeuwse tekst. 
dat een beproefde rest gespaard blijft en het begin vormt van het vernieuwde volk van God. Zo'n positieve kentering is er ook na de moord op de geheimzinnige figuur uit 12:10. Degenen die hem doorstoken hebben, keren zich weer tot God en rouwen over de dood van hun leider. Er is dus telkens wel sprake van een gewelddadige dood, maar dat gebeuren wordt achteraf betreurd en zijn dood is een offerdood die heilzame effecten heeft. Dat een profeet of een messiaanse figuur, die zelf op een geweldloze wijze optreedt, veel moet lijden en juist daardoor een nieuwe toekomst kan openen, is ook te vinden in Jesaja 53:4 en Psalm 69:27. Wellicht moeten de teksten uit Zacharia over het lot van de herder mede verstaan worden in het licht van deze teksten.

Blijft staan dat de uitspraken over de herder in Zacharia gekenmerkt worden door een zekere dubbelheid. In Matteüs wordt dit kluwen ontward en wordt duidelijk geopteerd voor de positieve interpretatielijn. De eerste evangelist staat hierin niet alleen; ook andere vroeg-christelijke auteurs hebben het optreden van Jezus verhelderd aan de hand van stof uit Zacharia (Black 2008:97-114; Hübenthal 2006:217255; McAfee Moss 2008:157-169).

\section{Van Zacharia naar Matteüs: Semantische transformaties}

Op basis van expliciete citaten uit Deutero-Zacharia wordt Jezus door Matteüs gepresenteerd als een vredevorst en een zorgzame herder. Dat de koning van Sion niet oorlogszuchtig is maar vredelievend wordt al in Zacharia 9:9 uitgesproken en sluit aan bij irenische teksten uit de Psalmen. ${ }^{32}$ Nieuw is dus niet dat Matteüs irenische kenmerken toeschrijft aan de messiaanse koning, maar nieuw is wel dat hij de aloude profetie uit Zacharia 9:9, die zelf niet duidelijk refereert aan een bepaalde historische figuur, bewaarheid ziet in het historisch optreden van Jezus, de zoon van David.

Nog creatiever is Matteüs' interpretatie van teksten uit Zacharia over een verworpen en vermoorde herder. Hij leest deze teksten als een soort fotografisch negatief waaruit hij een positief beeld van Jezus als herder weet te ontwikkelen. Terwijl negatieve en positieve elementen in de originele teksten met elkaar verstrengeld zijn, splitst Matteüs deze elementen uit over verschillende personages, waarbij Judas, die staat voor afvallige volgelingen van Jezus, en de hogepriesters en oudsten als slechte herders uit de bus komen, en Jezus als de ware herder. In Matteüs' citaat uit Zacharia 13:7 is de herder een positief te waarderen figuur, terwijl de pre-tekst hier zowel een positieve als een negatieve interpretatie toelaat. Juist vanwege hun dubbelzinnigheid en hun vaagheid en vanwege de open plekken die zij vertonen, laten teksten uit Zacharia ruimte voor nieuwe interpretaties. Matteüs benut deze ruimte om zijn verhaal over Jezus te verbinden met het literaire erfgoed van Israël maar tegelijk neemt hij de vrijheid om nieuwe en eigen accenten te leggen.

32.Bijvoorbeeld: Psalm 20:8; 33:16-17; 44:7; 46:9-10; 147:10-11
Mijn intertekstuele analyse wijst uit dat een marcionitische tegenstelling tussen de oorlogszuchtige God van het Oude Testament en de vredelievende Jezus van het Nieuwe Testament geen recht doet aan de besproken teksten. ${ }^{33}$ Vreedzame opties zijn ook in het Oude Testament te vinden, niet alleen in het Nieuwe, en gewelddadige praktijken treffen we ook aan in het Nieuwe Testament, en niet alleen in het Oude. Deze mengeling is ook aan Matteüs niet helemaal vreemd. Soms presenteert het eerste evangelie Jezus als iemand met een Januskop, als een personage met een dubbel gezicht. In zijn ethiek keert hij zich tegen het gebruik van fysiek en verbaal geweld, hij pleit voor geweldloosheid, vijandsliefde, vergeving en barmhartigheid en hij brengt deze keuzes ook zelf in praktijk, maar tegelijk laat Matteüs hem ook zeggen dat hij geen vrede is komen brengen maar het zwaard (10:34) $)^{34}$ en legt hij hem tal van tirades in de mond tegen de Farizeeën en schriftgeleerden, die moeilijk te verzoenen zijn met de bewering dat iemand die een ander uitmaakt voor dwaas het hellevuur verdient. Maar het meest inconsistent is volgens recente auteurs dat Jezus, die in Matteüs doorgaans de brenger is van een vreedzame ethiek, juist in dit evangelie een gewelddadige rol speelt doordat hij als rechter bij het laatste oordeel goddeloze mensen op een wrede manier afstraft. ${ }^{35}$

Enig commentaar op deze bewering is wel gewenst. Mijn intertekstuele analyse wees uit dat aan Jezus rollen worden overgedragen die in Zacharia toekomen aan God. Jezus is koning, zoals God koning is; Jezus is de ware herder, zoals God dat is. De vraag is nu of op Jezus in Matteüs ook de rol wordt overgeheveld die God in Deutero-Zacharia speelt als aanvoerder van de eindstrijd in de eindtijd. Is Jezus' rol bij het eindoordeel wel te vergelijken met de imperialistische wijze waarop God de wereldwijde vrede in Zacharia tot stand brengt? ${ }^{36}$

Er is een overeenkomst doordat 'alle macht in de hemel en op aarde', die aan God toekomt, in Matteüs in handen van Jezus wordt gelegd (11:27; 28:18). Als daarbij al sprake is van geweld, dan ligt het geweldsmonopolie bij God of bij Jezus, en is het niet aan mensen om zelf met geweld orde op zaken te stellen. Volgens Neville $(2013: 30,39)$ is dit strikte onderscheid tussen goddelijk een menselijk gebruik van geweld geen afdoende oplossing van de spanning tussen Jezus' vreedzame ethiek en zijn rol als geweldenaar bij het laatste oordeel.

\footnotetext{
33.Swartley (2006:85-87) construeert naar mijn oordeel een valse tegenstelling tussen Jezus' inzet in woord en daad voor Gods koninkrijk, dat een rijk van vrede tussen Jezus' inzet in woord en daad voor Gods koninkrijk, dat een rijk van vrede
is, en 'Israel's own messianic hopes', die hij - ten onrechte - vooral inkleurt is, en 'Irael's own messianic hopes', die hij - ten onrechte - vooral inkleurt
vanuit 'messianic texts in the intertestamental traditions that expected military destruction of the enemies'. Desjardins (1997:111) daarentegen wijst erop dat ook in het Nieuwe Testament vrede en geweld nauw met elkaar verweven zijn: 'The New Testament strongly promotes peace and strongly promotes violence.'

34.Sim (2000:103) interpreteert dit vers als volgt: 'Jesus brings the sword which cuts families in half as an integral component of the eschatological woes. He will also bring the sword (of God) at his parousia when he completely defeats his enemies in the final battle of history. Finally, he brings the sword to the final judgment, where he condemns the wicked and assigns them to eternal torment in the fires of Gehenna.'

35.Sim (1996); Reid (2004): Carter (2005); Neville (2007). Neville (2013:19) spreekt over 'the disturbing discrepancy between Matthew's portrayal of Jesus as a teacher of nonretaliation and Matthew's own violently retributive eschatology'.

36. Het nu volgende steunt mede op Weren (2014:218-221)
} 
Een belangrijk verschil met Zacharia is dat de met zoveel macht beklede Jezus zich niet ontpopt als een militante bestrijder van zijn vijanden maar dat hij tot de voleinding van de wereld vooral daar present is waar armen en verdrukten zich bevinden en zich laat ontmoeten waar hun nood gelenigd wordt (25:31-46).

In Zacharia heeft het eschatologisch drama het karakter van een vergeldingsoorlog die gericht op de vernietiging van Gods tegenstanders, de veroorzakers van het kwaad, terwijl Matteüs deze voorstelling vervangt door het - eveneens uit het Oude Testament afkomstige - idee dat op het einde der tijden een forensisch oordeel plaatsvindt, waarbij Jezus als rechter optreedt en alle mensen beloont of bestraft op grond van ethische criteria en niet op basis van het toebehoren tot een bepaalde etnische of religieuze groepering.

Door de klemtoon te leggen op het goede handelen verschuift Matteüs het brandpunt van de wereld die nog komen moet naar de geschiedenis die daaraan voorafgaat; hij focust niet op wat er op het einde zal gebeuren maar op wat er nu gedaan moet worden. Hij ziet de geschiedenis niet als een proces van steeds verder gaande degeneratie maar als de ruimte waarin mensen zelf een keerpunt ten goede kunnen realiseren als zij zich houden aan de Thora en Jezus daarbij als hun ethisch paradigma beschouwen.

Deze kanttekeningen maken duidelijk dat het wel een erg massief idee is om te stellen dat de Jezus van Matteüs een gewelddadige rol speelt op het einde der tijden. Zoals tijdens zijn eigen leven barmhartigheid hoog in zijn vaandel stond, zo zal hij bij het eindoordeel ook barmhartig zijn voor allen die barmhartig zijn geweest voor anderen $(5: 7 ; 25: 31-46){ }^{37}$

\section{Een vraag tot besluit}

Ik sluit mijn betoog af met een prangende vraag: wat is de actuele relevantie van Matteüs' visie op geweld en vrede? Deze vraag dringt zich op omdat zijn opvattingen niet op alle punten afgestemd zijn op de realiteit van onze situatie aan het begin van de 21ste eeuw. Zowel aan Zacharia als aan Matteüs is een zeker exclusivisme niet vreemd. In Zacharia moeten alle volkeren zich affiliëren met de Joodse gemeenschap in Jeruzalem; zij moeten zich scharen achter de cultus van JHWH die de ene en enige God is. In Matteüs vindt op dit punt een verbreding plaats van het perspectief doordat niet de tempelcultus het centrum vormt van de geloofsgemeenschap maar de Thora zoals die door Jezus is geïnterpreteerd; zijn boodschap moet wereldwijd verbreid worden en staat open voor alle volkeren. Maar ondanks deze universele oriëntatie treffen we ook hier een particularistische waarheidsclaim aan: Jezus is voor zijn volgelingen de enige ware leraar $(23: 8,10)$. Mijn prangende vraag is of sacrale teksten zoals die van Zacharia en Matteüs die weinig ruimte laten voor andere religieuze stromingen niet ook zelf gemakkelijk een bron

37.Dat barmhartigheid en broeder- en zusterschap centrale waarden zijn in Matteüs, is uitgewerkt in Weren (1994). Neville (2013:38-44) meent dat de gewelddadige en wraakzuchtige rol van Jezus bij het eindoordeel kan worden gerelativeerd en gedeconstrueerd vanuit Matteüs' eigen getuigenis over Jezus' keuze in woord en daad voor barmhartigheid en verzoening. worden van geweldsexplosies. Hoe kunnen deze teksten zo worden geïnterpreteerd dat zij een vruchtbare bijdrage leveren aan een samenspel waarbinnen verschillende religies en culturen elkaar kunnen zien als wegen naar echte mondiale vrede?

\section{Tegenstrijdige belangen}

De auteur verklaart geen financiële of persoonlijke belangen te hebben die hem ongepast kunnen hebben beïnvloed bij het schrijven van dit artikel.

\section{Literatuurverwijzingen}

Black, M.C., 2008, 'The messianic use of Zechariah 9-14 in Matthew, Mark, and the pre-Markan tradition', in P. Gray \& G.R. O'Day (eds.), Scripture and traditions: Essays on early Judaism and Christianity in honour of Carl R. Holladay, pp. 97114, Brill, Leiden. (Supplements to Novum Testamentum 129). http://dx.doi. org/10.1163/ej.9789004167476.i-504.38

Boda, M.J. \& Porter, S.E., 2005, 'Literature to the third degree: Prophecy in Zechariah 9-14 and the passion of Christ', in R. David \& M. Jinbachian (eds.), Traduire la Bible Hebraïque. De la Septante à la Nouvelle Bible Segond, pp. 215-254, Médiaspaul, Montréal. (Sciences bibliques études 15).

Brouwer, C., 1949, Wachter en herder: Een exegetische studie over de herder-figuur in het Oude Testament, inzonderheid in de pericopen Zacharia 11 en 13:7-9, H. Veenman en Zonen, Wageningen.

Brown, R.E., 1994, The death of the Messiah: From Gethsemane to the grave, vol. 1 , Geoffry Chapman, London. (The Anchor Bible reference library).

Carter, W., 2005, 'Constructions of violence and identity in Matthew's gospel', in S. Matthews \& E.L. Gibson (eds.), Violence in the New Testament, pp. 81-108, T\&T Clark, London.

Collins, T., 2003, 'The literary contexts of Zechariah 9:9', in Ch. Tuckett (ed.), The book of Zechariah and its influence, pp. 29-40, Ashgate, Aldershot/Burlington.

Davies, W.D. \& Allison, D., 1997, A critical and exegetical commentary on the Gospel according to Saint Matthew, vol. III: Commentary on Matthew XIX-XXVIII, T\&T Clark, Edinburgh

Desjardins, M., 1997, Peace, violence, and the New Testament, Sheffield Academic Press, Sheffield. (The biblical seminar 46).

Ellul, D., 1981, 'Variations sur le thème de la guerre sainte dans le Deutero-Zacharie', Études théologiques et religieuses 56(1), 55-71.

Floyd, M.H., 2002, 'The מַַׁ (Maśśa) as a type of prophetic book', Journal of Biblical Literature 121, 401-422. http://dx.doi.org/10.2307/3268153

Floyd, M.H., 2003, 'Deutero-Zechariah and types of intertextuality', in M.J. Boda \& M.H. Floyd (eds.), Bringing out the treasure: Inner biblical allusion in Zechariah 9-14, pp. 225-244, Sheffield Academic Press, London/New York, NY. (JSOT supplement series 370 )

Foster, P., 2003, 'The use of Zechariah in Matthew's gospel', in Ch. Tuckett (ed.), The book of Zechariah and its influence, pp. 65-85, Ashgate, Aldershot/Burlington, VT.

Gonzalez, H., 2013, 'Zechariah 9-14 and the continuation of Zechariah during the Ptolemaic period', Journal of Hebrew Scriptures 13, 1-43.

Gundry, R.H., 1982, Matthew: A commentary on his literary and theological art Eerdmans, Grand Rapids, MI.

Ham, C.A., 2005, The coming king and the rejected shepherd: Matthew's reading of Zechariah's messianic hope, Phoenix Press, Sheffield. (New Testament monographs 4)

Haubeck, W. \& Von Siebenthal, H., 1997, Neuer sprachlicher Schlüssel zum griechischen Neuen Testament, Matthäus bis Apostelgeschichte, Brunnen-Verlag, Giessen/Basel.

Hobbs, T.R., 1996, 'The language of warfare in Zechariah 9-14', in J. Barton \& D.J. Reimer (eds.), After the exile: Essays in honour of Rex Mason, pp. 103-128, Mercer University Press, Macon, GA.

Hübenthal, S., 2006, Transformationen und Aktualisierung: Zur Rezeption von Sach 9-14 im Neuen Testament, Katholisches Bibelwerk, Stuttgart. (SBB 57).

Jonge, H.J. de, 2003, 'The cleansing of the temple in Mark 11:15 and Zechariah 14:21', in Ch. Tuckett (ed.), The book of Zechariah and its influence, pp. 87-100, Ashgate, Aldershot/Burlington.

Jonge, M. de, 1992, 'Messiah', Anchor Bible Dictionary 4, 777-788.

Koehler, L. \& Baumgartner, W., 1958, Lexicon in Veteris Testamenti libros, Brill, Leiden.

Köhler, B., 1971, 'Sacharja IX 9: Ein neuer Übersetzungsvorschlag', Vetus Testamentum 21, 370. http://dx.doi.org/10.1163/156853371X00470

Larkin, K.J., 1994, The eschatology of Second Zechariah: A study of the formation of a mantological wisdom anthology, Kok Pharos, Kampen. (Biblical exegesis and theology 6).

Leske, A.M., 2000, 'Context and meaning of Zechariah 9:9', Catholic Biblical Quarterly 62, 663-678. 
Mason, R., 2003a, 'Use of earlier biblical material in Zechariah 9-14: A study in inner biblical exegesis', in M.J. Boda \& M.H. Floyd (eds.), Bringing out the treasure: Inner
biblical allusion in Zechariah 9-14, pp. 1-208, Sheffield Academic Press, London/ biblical allusion in Zechariah 9-14, pp. 1-208,
New York, NY. (JSOT supplement series 370).

Mason, R., 2003b, 'Why is Second Zechariah so full of quotations?', in Ch. Tuckett (ed.), The book of Zechariah and its influence, pp. 21-28, Ashgate, Aldershot/ Burlington.

McAfee Moss, C., 2008, The Zechariah tradition and the Gospel of Matthew, de Gruyter, Berlin/New York, NY. (Beihefte zur Zeitschrift für die neutestamentliche Wissenschaft 156).

Menken, M.J.J., 2011, 'Striking the shepherd: Early Christian versions and interpretations of Zechariah 13,7', Biblica 92, 39-59.

Meyers, C. \& Meyers, E.M., 1992, 'Zechariah 1-8', Anchor Bible Dictionary 6, $1061-$ 1065.

Neville, D.J., 2007, 'Towards a theology of peace: Contesting Matthew's violent eschatology', Journal for the Study of the New Testament 30, 131-161. http:// dx.doi.org/10.1177/0142064X07084773

Neville, D.J., 2013, A peaceable hope: Contesting violent eschatology in New Testament narratives, Baker Academic, Grand Rapids, MI.

Nolland, J., 2008, 'The king as shepherd: The role of Deutero-Zechariah in Matthew', in Th.R. Hatina (ed.), Biblical interpretation in early Christian gospels, vol. 2: The Gospel of Matthew, pp. 133-146, T\&T Clark, London/New York, NY. (Library of New Testament Studies 310).

Petersen, D.L., 1992, 'Zechariah 9-14', Anchor Bible Dictionary 6, 1065-1068.

Petterson, A.R., 2009, Behold your king: The hope for the house of David in the book of Zechariah, T\&T Clark, New York, NY/London. (Library of Hebrew Bible/Old Testament Studies 513).

Redditt, P.L., 1989, 'Israel's shepherds: Hope and pessimism in Zechariah 11:4-17' Catholic Biblical Quarterly 51, 631-642.

Redditt, P.L., 1993, 'The two shepherds in Zechariah 11:4-17', Catholic Biblical Quarterly 55, 676-686.

Redditt, P.L., 1994, 'Nehemiah's first mission and the date of Zechariah 9-14', Catholic Biblical Quarterly 56, 664-678.

Reid, B., 2004, 'Violent endings in Matthew's parables and Christian nonviolence', Catholic Biblical Quarterly 66, 237-255.
Roberts, J.J.M., 2004, 'The end of war in the Zion tradition: The imperialistic background of an Old Testament vision of world wide peace', Horizons in Biblical Theology 26(1), 2-22. http://dx.doi.org/10.1163/187122004X00023

Rose, W.H., 1998, 'Messianic expectations in the early post-exilic period', Tyndale Bulletin 49(2), 373-376.

Rose, W.H., 2000, Zemah and Zerubbabel: Messianic expectations in the early postexilic period, Sheffield Academic Press, Sheffield. (JSOT supplement series 304).

Schama, S., 2013, De geschiedenis van de Joden, deel 1: De woorden vinden 1000 v.C.-1492, Atlas Contact, Amsterdam/Antwerpen.

Schellenberg, A.F., 2001, 'One in the bond of war: The unity of Deutero-Zechariah', Didaskalia 12, 101-115.

Sim, D., 1996, Apocalyptic eschatology in the Gospel of Matthew, Cambridge University Press, Cambridge. (SNTS monograph series 88). http://dx.doi.org/10.1017/ CBO9780511555084

Sim, D., 2000, 'The sword motif in Matthew 10:34', HTS Teologiese Studies/Theological Studies 56, 84-104. http://dx.doi.org/10.4102/hts.v56i1.1698

Steyn, G.J., 2012, 'The text form of the Isaiah quotations in the Sondergut Matthäus compared to the Dead Sea Scrolls, Masoretic Text and Septuagint', in J. Cook \& H.-J. Stipp (eds.), Text-critical and hermeneutical studies in the Septuagint pp. 427-446, Brill, Leiden. (Supplement to Vetus Testamentum 157). http:// dx.doi.org/10.1163/9789004241732_023

Swartley, W.M., 2006, Covenant of peace: The missing peace in New Testament theology and ethics, Eerdmans, Grand Rapids, MI/Cambridge.

Tilborg, J. van, 1989, 'Matthew 27,3-10: An intertextual reading', in S. Draisma (ed.), Intertextuality in biblical writings: Essays in honour of Bas van lersel, pp. 159-174, Kok, Kampen.

Weis, R., 1992, 'Oracle', Anchor Bible Dictionary 5, 28-29.

Weren, W.J.C., 1994, 'Broederschap en barmhartigheid in Matteüs: Een tekstsemantische studie', in D. Akerboom e.a. (red.), Broeder Jehosjoea, pp. 249-265, Kok, Kampen.

Weren, W.J.C., 1999, Windows on Jesus: Methods in gospel exegesis, SCM, London/ Trinity Press International, Harrisburg, PA.

Weren, W.J.C., 2014, Studies in Matthew's gospel: Literary design, intertextuality, and social setting, Brill, Leiden/Boston, MA. (Biblical interpretation series 130). 